\title{
Geç Kapitalist Dönemde Başarı-Başarısızlık: Dizi Gerçekliği ${ }^{1}$
}

\section{Achievement-Failure in the Late Capitalist Period: Reality of Serial}

\author{
Dr. Öğr. Üyesi Aslıhan Akkoç²
}

Başvuru Tarihi: 16.09.2018

Kabul Tarihi: 23.12.2019

\section{Öz}

Bu çalışmayla başarı ve başarısızlığın toplumsal boyutlarını tartışmak amaçlanmaktadır. Geç kapitalist dönemde, modern ilişkiler sistemi içinde insanlar toplumsal ve toplumlar arası koşullardan büyük oranda etkilenmektedirler. Özellikle de geç kapitalist dönemde küresel, toplumsal, iktisadi ve kültürel unsurlardan insanlar büyük ölçüde etkilenmektedirler. Pek çok şey gibi, kişisel başarı-başarısızlık da toplumsal koşullarla yakından ilişkilidir. Bir diğer açıdan da başarı, toplum tarafından insanlara atfedilen bir sıfattır. Başarı hem toplumda kazanılan bir şeydir, hem de bireysel koşulların ürünü olmanın yanında toplumsal koşullarla da ilişkilidir. Bunun yanında, geç kapitalist dönemin başarı algısı dikkat çekmektedir. Bu bağlamda televizyon dizilerinde aktarılan başarı algısını incelemek amaçlanmıştır. Çalışmanın kapsamı, bir televizyon dizisinde yer alan başarı sunumunun incelenmesi ve bunun yanında geç kapitalist koşullarda başarının toplumsal koşullar ile ilişkisi üzerine olacaktır.

Anahtar Kelimeler: Sosyoloji, Geç Kapitalizm, Modernizm, Başarı, Başarı-Başarısızlık, Televizyon Dizileri

\section{Abstract}

Through this study, it is aimed to discuss social dimensions of achievement and failure. People are affected from social and inter-social conditions on a large scale in the system of modern relationships in the late capitalist period. Especially, in the late capitalist period individuals are affected great degree from global, social, economic and cultural forms. Like other things, Individual achievement and failure is also related closely with social conditions. On the other hand, achievement is a title attributed to individuals by society. Achievement is a thing both gaining in the society, and is a related with social conditions besides being product of individual conditions. In addition, it is taken into consideration the achievement perception of late capitalist period. In this context, it is aimed to examine the achievement perception which is reflected in the tv serials. The extent of the study is to analyse the presentation of achievement in a tv serial and relationship with social conditions of the achievement in late capitalist process.

Keywords: Sociology, Late Capitalism, Modernizm, Achievement, Achievement-Failure, Tv Serials

\footnotetext{
1 Bu çalışma, 9-11 Nisan 2018 tarihlerinde İstanbul'da gerçekleşen 1st International Congress on New Horizons in Education and Social Science (ICES-2018) isimli kongrede bildiri olarak sunulmuştur.

2 Afyon Kocatepe Üniversitesi Fen Edebiyat Fakültesi Sosyoloji Bölümü, aslhanakkoc@gmail.com, ORCID: 0000-0002-1827-4339
} 


\section{Giriş}

Bu çalışmada televizyon dizilerinde, başarıya ulaşmada bireylerin şartlarının nasıl tanımlandığı ve bu durumun geç kapitalist koşullarla ilişkisi üzerinde durmak amaçlanmıştır. Diziler, gerçek ve kurgu karışımı yansıttıkları yaşam düzeni içinde başarı ve başarısızlık hakkında neler ortaya koymaktadırlar? Çalışmada başarı ve başarısızlık kavramının ele alınması ve dizinin incelenmesi sosyolojik bir perspektiften olacaktır. Sosyolojik bir ele alış ile geç kapitalist koşullar ve bu koşulların ortaya çıkardığı başarı algısını tartışmak amaçlanmaktadır.

Bu çalışmayı gerçekleştirirken neden televizyon dizilerini ele alma ihtiyacı duyulduğundan bahsetmek gerekmektedir. Medya insanların en yoğun olarak ilgilendikleri ve özellikle ilişki içine girdikleri sosyal alanları oluşturmaktadır. Yeni medya unsurlarının katkıları ve etkileriyle diziler halen toplumda takip edilme bakımından cezbedici bir zaman geçirme türü olmayı sürdürmektedirler. Bu nedenle, toplumda televizyon dizileri önemli ölçüde insana ulaşabilen bir özelliğe sahiptir. Bu çalışma ile amaçlanan, bir televizyon dizisinden hareketle, geç kapitalist dönemde başarı ve başarısızlığın nasıl yansıtıldığına dair bir ele alış biçimi ortaya koymaktır.

Türkiye'de televizyon dizilerinin farklı kavramlar ve konular üzerinden ele alınması ve incelenmesi mümkündür. Bu konuda pek çok örnek söz konusudur. Türkiye’de televizyon kültürünün gelişiminin, farklı dizi türlerinin incelendiği ve izleyici araştırmalarının yapıldığ Aydan Özsoy'un (2011) Televizyon ve İzleyici: Türkiye'de Dönüşen Televizyon Kültürü ve İzleyici adlı çalışmasından bahsedilebilir. Televizyon dizilerinin incelenmesinde farklı kimlikler temelinde meseleye bakılarak dizilerin ele alındığ çalışmalar da mevcuttur. Ece Ünür’ün (2015) Yerli Dizilerdeki Kimlik Kalıpları adlı çalışması bu konuda ifade edilebilir. Bunun yanında, dizi analizi açısından farklı yöntemler kullanılarak yayınlanan makaleler söz konusudur. Levent Doyuran'ın (2018) Medyatik Bir Çalışma Alanı Olarak Eleştirel Söylem Çözümlemesi (Televizyon Dizileri Örneğinde), E. Gülbuğ Erol'un (2009) Asmalı Konak Dizisi ve Filmi Üzerine Anlatı Kuramı Açısından Bir Değerlendirme, Özge Güven Akdoğan'ın (2019) Kadınların Finansal Okuryazarlı̆̆ı ve Finansal Becerileri Üzerine Bir Yerli Dizi Analizi, Hacı Özdemir’in (2018) Türkiye'de Yerli Televizyon Dizilerinde Toplumsal Cinsiyet Rolleri Açısından Kadının Sunumu: Aşk-ı Roman Örneği, Emel Kökpınar Kaya’nın (2017) Dilsel Kod ve Gösterge Arayüzünde 'Zengin' ve 'Fakir' İnşası: Bir Yerli Televizyon Dizisinin Eleştirel Söylem Çözümlemesi adlı çalışmalardan bahsedilebilir. Televizyon dizi analizlerinde ele alınan konular yaygın olarak farklı kimlikler temelinde yapılan analizler, geleneksel özelliklerle modern alışkanlıkların bir araya gelmesinin değerlendirilmesi, cinsiyetçi bakış açısının ve kadının dizilerde nasıl sunulduğunun ele alınması, farklı kimlikler olarak zengin ve fakir kimliklerinin inşasının ele alınması gibi çeşitli konularda ağırlık kazandığı görülmektedir. Televizyon dizi analizlerinde konu olarak başarı kavramı üzerinden bir ele alış, inceleme ve dönemin kapitalist toplumsal koşullarıyla ilişkilendirilerek başarının anlamlandırması bağlamında yazında bir boşluk olduğu görülmektedir. Dolayısıyla çalışmanın özgün yanı, inceleme konusu olarak televizyon dizilerinde başarının nasıl sunulduğunun incelenmesinden ve başarı sunumundan yararlanarak dönemin küresel, geç kapitalist ilişkileri içinde kişisel başarı-başarısızlığın nasıl anlamlandırılabileceğini ortaya koymasından kaynaklanmaktadır. Bu bakımından çalışmanın konusu önem taşımaktadır. Çalışmanın amacı sadece dizi analiziyle sınırlı değildir, buradan 
edinilen verilerden hareketle dönemin küresel, kapitalist ilişkiler sisteminin içinde ele almasıdır. Bu nedenle ele alış biçimi farklılık taşımaktadır.

Bu çalışmada, özellikle dizide başarıya ulaşma süreçlerinin nasıl aktarıldığı ve başarının dizide nasıl tanımlandığı incelenmiş ve değerlendirilmiştir. Bu bağlamda, dizi incelemesinde, eleştirel söylem çözümlemesi yöntemi kullanılmıştır. Dizide, kişilerin başarıya ulaşma süreçleri bireysel özelliklerde mi bulunmaktadır, yoksa bireyin içinde bulunduğu toplumlar arası, toplumsal ve bireysel koşulların bir bütünü olarak mı gösterilmektedir? Çalışmada bu konuları tartışmak amaçlanmaktadır.

Ayrıca çalışmada geç kapitalist dönemde başarı kavramı sosyolojik bir ele alışla irdelenecektir. Öncelikle geç kapitalist dönemin genel özelliklerinden bahsedilecektir. Daha sonra geç kapitalist dönemde ortaya çıkan başarı algısının ana hatları ortaya konulacaktır. Çalışmada bu konuları ele almak ve tartışmak amaçlanmaktadır.

\section{Geç Kapitalist Dönemin Özellikleri}

Endüstriyel kapitalizm, Batı Avrupa'da ortaya çıkan yeni üretim yapısının kâr odaklı bir biçimde sermayeyi devamlı büyütme döngüsü olarak en sade biçimde ifade edilebilir. Endüstri devriminin başlangıcının 18.yy'ın sonuna doğru gerçekleştiği kabul edilir (Hobsbawm, 2008, s.37-38). Kapitalist süreç kendi bünyesi gereği açmazlar içeren, ekonomik ve toplumsal sorunlar üreten bir özelliğe sahiptir. Kapitalist süreci ortaya çıkışından itibaren birkaç gelişme aşamasıyla Mandel (2013) tanımlamaktadır. Mandel'e (2013, s. 130-131) göre, bunlardan ilki 18.yy'in sonundan 1847 sürecine kadar manifaktürün belirleyici olduğu endüstri devrimi uzun dönemidir. İkincisi, $1847^{\prime}$ den $1890^{\prime} l$ yllara kadar devam eden birinci teknolojik devrim dönemi olarak adlandırlır. Bir diğeri, 1890'lı yllardan İkinci Dünya Savaşı’na kadar devam eden ikinci teknolojik devrim dönemidir. Kuzey Amerika'da 1940'larda, diğer ülkelerde 194548 arasında başlayan süreç ise, üçüncü teknolojik devrim dönemi olarak (Mandel 2013, s. 130131) nitelendirilir. Kapitalist üretim tarzının 20.yy'da Dünya Savaşları sonrası sürecini açıklama çabasında Mandel’in geç kapitalizm kavramsallaştırmasını kullandığı görülür. Mandel (2013, s.25-27) geç kapitalizm kavramılla, apayrı özelliklere sahip bir kapitalist süreç olmadığını yani kapitalizmin emperyalist özelliğinin değişmediğini vurguladığı görülür. Hatta Mandel, (2013, s. 27) geç kapitalist aşamayı emperyalist, tekelci kapitalizmin daha ileri evresi olarak değerlendirmektedir. Mandel'e (2013, s. 27) göre dönemi açıklamak, döneme isim vermekten daha fazla önem taşımaktadır. Mandel'in (2013) geç kapitalizm analizinde değer yasası üzerine ve artı-kâr üzerine odaklandığı görülür. Mandel (2013) özellikle kapitalist uzun çevrimlerin her birinin önce genişleyen bir ekonomik büyüme sürecinin gerçekleştiği ve ardından da ekonomik daralma döneminin birbirini takip ettiği dönemlerden oluştuğu çözümlemesinde bulunmaktadır. Dolayısıyla, kapitalist süreç kendi özellikleri gereği ekonomik sorunlar, krizler içeren yapıya sahiptir. 20.yy'da Avrupa'da ve ABD'de refah politikaları, devlet müdahaleleri ve planlamaları bunun yanında Fordist üretim modeli önemli boyutta kapitalist sistemin sorunlarının aşılmasında, ekonominin canlanmasında ve sonuçta da tüketim kültürünün yaygınlaşmasında etkili olmuştur (Harvey, 2010, s. 147-163). Jameson’a (1994) göre, "geç kapitalizmin ekonomik yönden hazırlanışı...” (1994, s.22) 1950’li yıllarda başlamıştı. Yeni 
dönemin özelliklerinin 1945-1973 arası oluştuğunu belirtmektedir (Jameson, 1994, s.22). Bununla birlikte Jameson, (1994) geç kapitalizm kavramının önceki kapitalist süreçlerden farklılığını değil, sürecin devamlılığını gösteren bir kavram olarak ifade edildiğini belirtir (1994, s.20). Kapitalist sistemde ekonomik canlılık süreci Harvey'e (2010, s.147-163) göre 1973’lere kadar, Mandel'e (2013, s.132) göre de 1960'lı yılların ortalarına kadar devam etmiştir. Yine ekonomik büyümenin olduğu bir süreci ekonomik daralma dönemi izlemektedir.

Harvey savaş sonrası dönemdeki düşünce biçimlerinde süreksizlik, parçalanma, gelip geçicilik gibi özelliklerin sosyal kuramların gelişiminde üst anlatıların giderek ortadan kalkmasında, yeni dönemin olaylara bakış açısında toplumsal dünyanın süreksizleşmesi ve parçalanması yaklaşımının mimaride, çeşitli sanatlarda, ekonomik ve toplumsal yapıda bariz bir biçimde ortaya çıktığını vurgulamaktadır (Harvey, 2010, s. 60-83). Harvey (2010) post modernizm olarak adlandırılan bu düşünce biçiminin tarihsel süreklilik ve bellek duygusunun ortadan kalkmasıyla ve bunun yanında zamansallığın yitiminin de gelmesiyle ilişkili olduğunu vurgulamaktadır (2010, s. 60-83). Süreksizlik, gelip geçicilik, parçalanma gibi özellikler gösteren dönem, tarihsel ve toplumsal yani süreçsel olanla ilişkisiz, kopuk hale gelmektedir. Dolayısıyla süreksizleşme, gelip geçicilik gibi özelikler toplumsallıktan kopma, soyutlaşma sorununu da beraberinde getirmektedir. Harvey, sosyal bilimsel kuramsal çözümlemelerden, sanatsal alanlara, iletişim ve tüketime kadar gözlenebilen süreksizleşme, tarihsel süreklilik ve bellek duygusunun yitiminin kanıtlarını ortaya koymaktadır (Harvey, 2010, s. 60-83). Ayrıca Harvey (2010) dönemi analiz ederken "Kapitalizmin yüzey görünümünde 1973’ten bu yana bütünsel bir değişim yaşandığını, ama kapitalist birikimin temelde yatan mantığının ve kriz eğilimlerinin hâlâ aynı olduğunu ileri sürmüş bulunuyorum.” şeklinde meseleye yaklaşmaktadır (2010, s. 215). Kapitalizmi oluşturan temel niteliklerde bir değişim söz konusu değildir. Ancak kapitalizmin sorunlu dönemlerinde sorunların aşılmasını sağlama noktasında değişimler ve dönüşümler gerçekleşmektedir. Bu değişim ve dönüşümlerin esas nedeni, kapitalizm dışında yeni koşulların oluşmasından değildir, kapitalizmin devamlılığını sağlama çabasıdır. Kapitalist ekonominin sorunlarını aşmaya yönelik, 1970’li ve 1980’li yıllarda yeni bir ekonomik yaklaşım modeli olarak esnek birikim ortaya çıkmıştır (Harvey, 2010, s. 170). Esnek birikim süreci, Harvey'in bahsettiği süreksizleşme, gelip geçicilik, parçalanma, tarihsel süreklilik ve bellek duygusunun yitimi ile uyumlu bir ekonomik yaklaşımdır. Bu süreçte, toplumsal yaşamın diğer alanlarında olduğu gibi ekonomide de; istihdam, üretim ve tüketim yapılarında süreksizlik, gelip geçicilik, tarihsel süreklilik, bellek duygusunun yitimi dönemin karakteristik özelliğidir (Harvey, 2010, s.170-196). İstihdam yapısının esnek bir yapıya dönüşmesi, güvencesi olan tam zamanlı çalışma düzeninden, yarım zamanlı, sözleşmeli, geçici istihdam türlerine doğru ağırlıklı bir geçişi beraberinde getirir. Bunun yanında, emek üzerinde artan denetim ortaya çıkmaktadır. Çalışanların her türlü esnekliğe uygun olması beklenir. Esnek üretim ise, dünya genelinde farklı coğrafyalarda üretimin gerçekleştirilmesidir (Harvey, 2010, s.170-183). Bu yeni süreçte, ekonomide her şey esnek, belirsiz, akışkan bir hal almaktadır. Dolayısıyla esnek birikim yapısı, çalışanlar açısından belirsizlik, gelip geçicilik, güvensizlik, kaygı yaratan önemli problemlerden biridir. Belirsizlik ve akışkanlık, işgücünün bireysel yaşamından, uluslararası ekonomik piyasalara kadar genişleyen ölçülerde dönemin genel karakteri haline gelmiştir. 
Sennett (2017, s. 13-69) ve Bauman (2013, s. 122-132) önceki dönemlerde kişisel yaşamların özellikle de insanların meslek yaşamlarının, bununla bağlantılı amaçlarının ve beklentilerinin doğrusal bir çizgide ilerlediğinden planlanabilen bir yaşama olanak verdiğini vurgulamaktadırlar. Ancak yeni kapitalist koşullarda ortaya çıkan belirsizlik, sürüklenme, parçalanma özellikleri gösteren esnek süreçler dolayısıyla kişisel meslek yaşamlarının ve buna bağlı bir biçimde kişisel yaşamın bütün alt alanlarının daha belirsiz, daha kırılgan hale geldiğini vurgulamaktadırlar (Sennett, 2017 ve Bauman, 2013, s. 122-132). Dolayısıyla yeni kapitalist koşullarda insan psikolojisi, aile yaşamı güçsüzlük duygusu, güvensizlik, kaygı gibi sorunlarla baş başa kalmaktadır.

Dönemi anlamayı sağlayacak bir başka mesele de şu şekilde ifade edilebilir. Mandel'e (2013) göre geç kapitalist süreçte, araştırma faaliyetlerinin kapitalist üretim süreçleriyle ilişkilendirilmesinin daha önce hiç olmadığı ölçeğe ulaşmış olması nitelikli insan ihtiyacını arttırmıştır. Bu durum Mandel'in (2013, s. 253-263) üniversite patlaması dediği, yüksek öğrenime olan ilgiyi dünya genelinde günümüze kadar gitgide arttıran, teşvik eden bir süreci beraberinde getirmiştir. Buna ek olarak, bu süreçte ekonomik yaşamda, iş yapısı vasıfsızlaşmakta, parçalanmakta, esnekleşmekte ancak yüksek öğretim gören nitelikli insan sayısı dünya genelinde giderek artmaktadır. Bu durum da dünya genelinde yeni kapitalizmin çelişkili meselelerinden biri olarak insanların yaşamını etkileyen gelişmelerden biridir.

Ayrıca Mandel (2013, s. 495), geç kapitalizmde uzmanların belirleyici olduğunu ve teknolojiye duyulan inancın fazlasıyla geliştiğini vurgulamaktadır. Bunların yanında Mandel'e göre "Geç kapitalist toplumsal yapı ve ideoloji ayrıca zorlayıcı başarı çabası ve "teknolojik otorite" ye mekanik teslimiyet aşılar ki bu da sık sık nevrotik stres yaratır." (Mandel, 2013, s. 500). Zorlayıcı başarı çabasıyla özellikle birey üzerinde yaratılan psikolojik bir stresten Mandel bahsetmektedir. Mandel de geç kapitalist toplumsal koşulların birey yaşamı üzerindeki ve birey psikolojisi üzerindeki olumsuz etkisinin altını çizmektedir.

"Nihai olarak kapitalizmin kısmi rasyonelliği ile genel irrasyonelliği arasındaki çelişki sermayenin maksimum valorizasyonu ile kadın ve erkeklerin optimum öz-gerçekleştirmesi arasındaki çelişkiyi yansıtır” (Mandel, 2013, s.504). Kapitalist ilişkilerde üretim ve verimlilik ekseninde görülen rasyonelleşmenin artışına rağmen insanların kendilerini ekonomik, toplumsal ve kültürel açıdan geliştirmesini sağlayacak olanakların tam tersine bir hal içinde olmasını Mandel'in vurguladığı görülmektedir. Ekonomik rasyonelleşmeye rağmen toplumsal ve ekonomik sorunların, eşitsizliklerin devamını bir çelişki olarak Mandel görmekte ve rasyonelleşme ve irrasyonelleşmenin çelişkisi olarak nitelemektedir. Dünya genelindeki ekonomik rasyonelleşmeye rağmen insanların temel ihtiyaçlardan başlayarak, kendilerini geliştirmelerini sağlamalarının gitgide daha da zorlaşmış olması bahsedilen çelişkiyi ortaya koymaktadır. Ritzer (2016, s.131-152) de benzer bir yaklaşımda bulunmaktadır. Rasyonelleşmenin artışına, ekonomik hesaplanabilirlik ve standartlaşma gibi kapitalist üretimi hızlandırıcı unsurlara rağmen bir irrasyonellikten bahsetmektedir. Bir taraftan verimlilik, kâr ve büyüme ortaya çıarken bir diğer taraftan da ortaya çıan olumsuz sonuçlardan bahsetmektedir. İçinde bulunulan ekonomik üretim yapısı, toplumsal alanları fazlasıyla 
etkilemektedir. Sonuçta insan yaşamı, insani alanlar, insan psikolojisi de bu durumdan etkilemektedir.

Geç kapitalist ekonomik yapı, bireylerin meslek yaşamı üzerinde belirleyici bir niteliğe sahiptir. Geç kapitalist koşullarda birey yaşamı sadece bireysel koşullar içerisinde belirlenmemektedir. Bu dönemin genel karakteri olan belirsizlik, süreksizlik, parçalanma gibi özellikler bireylerin yaşamında merkezi bir rol oynar hale gelmiştir. Geç kapitalist koşulların ortaya koyduğu özellikler birey yaşamı ve özellikle de birey başarısı üzerinde etkili olmaktadır.

\section{Geç Kapitalist Dönemde "Başarı" Kavramı}

Geç kapitalist dönemde bireysellik ön plana geçmiştir. Bireylerin, düşünsel, yaşamsal, ekonomik anlamda kendi kendini inşa etmesi anlayışı gitgide yaygınlaşmakla birlikte, aslında geç kapitalist döneme ait karakter özellikleri dolayısıyla toplumsal koşulların, toplumsal bir varlık olan birey yaşamı üzerindeki etkisi daha da artmaktadır. Geç kapitalist ve modern koşullar birey yaşamı üzerinde belirleyici olan en önemli etmenlerden biridir. Dönemin en belirleyici karakteri belirsizlik, akışkanlık, parçalanma, tarihsel bütünsellik duygusunun yokluğudur. Toplumsal yaşamda bir süreç söz konusu değilse, tarihsel ve toplumsal zamansallık söz konusu değilse, yeni koşullara, değişimlere sürekli ayak uydurabilmek devamlı yeniden inşayı, Giddens'ın (2014) deyimiyle refleksif benlik tasarımını (2014, s. 103) gerekli kılar. Düşünümsellik, modern koşulların ortaya koyduğu benliğin sürekli yeniden inşası olarak karşımıza çıkmaktadır (Giddens, 2014, s.103-104). Giddens'a (2014) göre, "Modernizmin refleksivitesi, toplumsal etkinliğin çoğu yanının ve doğayla maddi ilişkilerin yeni malûmatlar veya bilgiler ışı̆̆ında sürekli gözden geçirilmeye açık olmasını ifade eder.” (2014, s.35). Özellikle modernizmin düşünümselliği, benlik yaratımına dahil olur, benlik refleksif bir tasarım haline gelir (Giddens, 2014, s.103). Giddens'a (2014, s. 51) göre refleksif benlik tasarımı sadece kriz zamanlarında görülmez, modern toplumsal etkinliğin psişik olarak genel bir özelliğidir. Giddens'a göre düşünümsellik, bireysel ve toplumsal süreçleri sürekli etkileyen karmaşı bir süreçtir. Bu açıdan modernizmin düşünümselliğini sağlayan toplumsal unsurların başında iletişim araçları gelmektedir. Bireylerin küresel, kapitalist yeni koşullarda kültürel açıdan sürekli yeniden inşa edilmesi söz konusudur. Bu konuda iletişim araçları önem taşımaktadır.

Geç modern dönemde, benliğin sürekli yeniden inşasında, bireylerin kişisel yaşamları, hayatını kurma biçimleri, hayata tutunma biçimleri de yeniden inşa edilmektedir. Bu yeniden inşa süreciyle, pek çok toplumsal alanın artık sadece bireysel alandan ibaret tanımlandığ görülmektedir. Bauman’a göre geç modern koşullarda “...başarılar kadar, sıkıntılarından da bireyin kendisi sorumludur.” (Bauman, 2014, s.196). Sorunlar sadece bireysel sorun olarak yansitılmaktadır. Dünya genelinde var olan geç kapitalist ve modern yapısal sorunlardan kaynaklı şekilde bireylerin yaşadığı sorunlar ve başarısızlıklar kendilerine mal edilmektedir. Başarı ve başarısızlık sadece bireysel yetenek ve dolayısıyla bireysel şartlarla açıklanmaktadır. Koşulları oluşturanın bireyin kendisi yani yeteneği olduğu iddiası söz konusudur. Toplumsal yaşamda başarının ve başarısızlı̆̆ın koşullarını bireyin kendisinin ve sadece yeteneğinin oluşturduğu vurgulanmaktadır. Dolayısıyla sorunlar, başarısızlıklar bireysel alana itilmektedir. 
Başarının, sadece bireyin sorumluluğuna ait bir alan olduğu kabul gören bir açılama haline gelmiştir.

Bu bağlamda, Sennett (2011) Yeni Kapitalizmin Kültürü adlı çalışmasında çalışma hayatında yeni koşullarda kişisel yeteneğe yapılan vurguyu ele almıştır. Modern koşulların istediği başarı yeni nesil potansiyel yetenekle olmaktadır (Sennett, 2011, s.11). Sennett, (2011, s.65) bu çalışmasında; yeteneği kişinin yapmayı öğrendiği şeyi yapması değil, yeni bir şey yapabilme yeteneği şeklinde tanımlamaktadır. Bildiğini daha iyi yapmak, bilgi ve deneyimi derinleştirmek anlamına gelirken, bununla beraber bu durum bir süreç gerektirir. Ancak bu yetenek türü tercih edilmemektedir. Aksine bilgiyi ve deneyimi derinleştiren bir yetenek değil, yeniyi öğrenebilme kapasitesi esas alınır. Sennett (2011, s.77) bu konuda “... deneyimden bağımsız kabiliyet fikri bir kurgudur.” diye açıklamaktadır. Sennett, yeni kapitalist kültürün toplumsal bağlamlarından kopartılmış bir yetenek ve başarı istediğini vurgulamaktadır. Yetenek arayışının, deneyim bağını kopardığını vurgulamaktadır (Sennett: 2011, s.78). Başarı, toplumsal ve bireysel koşulların bir bütünü olmakla birlikte, deneyim, bilgi birikimi, emek ve çaba süreci olmaksızın yeni koşullarda tanımlanmaktadır. Yetenek kavramı yeniden inşa edilmekte ve anlam olarak toplumsal özelliklerinden soyutlanmaktadır.

Geç modern dönemde, başarısızlık ise bireysel hatalar alanına dahil edilmektedir. Belirsizliklerin, başarısızlıkların aşılması bireysel alana bırakılmaktadır. Bauman da bu fikri vurgulamaktadır (Bauman, 2014, s. 129). Aslen küresel sorunların, çelişkilerin, belirsizliklerin bireysel çözümlerle aşılması gerektiği pratiğinin altı çizilmektedir. Oysa toplumsal yaşamda her toplumsal kesimin sorunları aşabilme imkânı farklılıklar taşımaktadır. Özellikle de kadınlar, yaşlılar, kırsal kesimler ve yoksul kesimler açısından bireysel imkanlarla sorunları aşmak ve başarıyı yakalamak oldukça zordur. Örneğin, iyi eğitim olanaklarını elde etmek, iyi bir kariyer ve statü sahibi olmak vs. imkanlar açısından toplumsal yaşamda farklılıklar söz konudur. Bu nedenle ekonomik açıdan yeterli gelire sahip olmayanlar, kadınlar, yaşlılar, kırsal kesimde yaşayanlar ...vs toplumsal kesimler açısından geç/yeni kapitalist koşullarda bireysellik vurgusu dolayısıyla karşılaşılan başarısızlığa çözümün sadece bireysel alanda aranmasına neden olmaktadır. Bu sayede kişisel hayatlar daha da karmaşıklaşmakta ve zorlaşmaktadır.

Bauman, (2005) başarı ya da başarısızlığın tamamen bireysel özelliklerle açıklanır hale gelişini somutlaştırmıştır.

"İşsiz kalmaları halinde bunun sebebi, bir iş görüşmesinden başarıyla çıkma becerilerini öğrenememeleri ya da bir iş bulmak için yeterince gayret göstermemeleri ya da tek kelimeyle işten kaçmalarıdır. Kariyer beklentilerinden emin olmamaları ve geleceklerini düşünerek acı çekmeleri halinde, bunun sebebi, dost kazanma ve insanları etkileme konusunda yeterince iyi olmamaları ve kendini ifade etme ve başkalarını etkileme sanatlarını öğrenmeyi başaramamış olmalarıdır. Onlara söylenen ve inanmaları sağlanan şey budur. Dolayısıyla, 'sanki' bu durum gerçeğin ta kendisiymiş gibi davranırlar...... Riskler ve çelişkiler toplumsal olarak üretilmeye devam eder..." (Bauman, 2005, s. 63-64). 
Başarı, kişisel özelliklerle (özellikle de yetenekle) gerçekleşiyorsa ve birey başaramıyorsa nedeni yine bireyin kendisi olarak içselleştirilir. Hatta psikolojik sorunlara neden olabilecek boyutta içselleştirilmiş olabilir. Bu konuda Giddens'ın (2014) modern toplumlara dair vurguladığı çözümleme anlamlı görünmektedir. “... varlıksal güvenlik esasen rutinler aracılı̆̆ıyla sürdürülür. Modern toplumsal koşullarda gündelik varoluş birçok bakımdan modern öncesi kültürlerdekine göre genelde daha kontrollü ve öngörülebilir olsa da, varlıksal güvenlik çerçevesi kırılgan hale gelir. Koruyucu koza refleksif benlik tasarımı içinde düzenlenen rutinlerin tutarlılığına giderek daha fazla bağımlı hale gelir.” (2014, s. 212). Belirsizliklerin, gelip geçiciliğin olduğu yani tutarlılığın olmadığı bir dünyada varlıksal güvenlik duygusu zarar görmektedir.

Sosyolojik olarak başarı ya da başarısızlığın toplumsal koşulların ve bireysel koşulların bütünü olduğunu ifade etmek gerekmektedir. Bunun yanında, başarı anlam olarak toplumsal içeriklidir. Çünkü, toplumdan topluma kimin başarılı veya başarısız olduğu değişmektedir. Başarı ve başarısızlık özellikle içinde bulunulan toplumun değerlerine göre anlam kazanan bir yapıya sahiptir. Başarı ve başarısızlığın göreceli bir kavram olduğu anlaşılacaktır. Dolayısıyla başarı ve başarısızlık toplum tarafından bireylere atfedilen yani insanlar tarafından genellikle öteki bireylere atfedilen bir kavramdır. Anlam, toplumsal koşullar tarafından ve toplum tarafından yüklenmektedir. Kimi zaman, bir toplumda zengin olmak başarı kabul edilirken, başka bir toplumda ise, maddi birikimden öte bilgi, sanat ve düşünce birikimi bir başarı olarak nitelenebilir. Başarı veya başarısızlık payesi; diğer insanlar tarafından bireye verilen bir sıfat olmaktadır. Dolayısıyla, başarı-başarısızlık kavramları, toplum tarafından bireye atfedilen bir tür statüdür. Buna ek olarak başarı; ekonomik koşulların, eğitim koşullarının ve uzun bir süreç gerektiren uğraşıların, deneyimin, çabanın ve toplamda bakıldığında toplumsal koşulların getirdiği imkânlar veya sınırlılıklar olarak karşımıza çıkmaktadır. Dolayısıyla, başarı toplumsal yaşam içinde; bilgi birikimiyle, deneyimle, emek ve zaman sarf edilmesiyle gerçekleşmektedir. Bilgi birikimine, deneyime sahip olmak, emek sarf etmek bir zamansallık içerisinde yani, toplumsal bir süreç içerisinde ortaya çıkabilir. Dolayısıyla hangi boyutuyla incelenirse incelensin başarı, toplumsal içeriklidir. Başarıyı sadece kişisel koşulların ürünü olarak değerlendirmek mümkün gözükmemektedir.

Geç kapitalist ve geç modern ilişkiler, küresel düzeyde toplumsal, ekonomik, kültürel yaşamı belirleyen parçalanma, belirsizlik, süreksizlik, gelip geçicilik gibi temel özelliklere sahiptir. Buna bağlı olarak, dünya genelinde ekonomik, sosyal sorunlar giderek artmaktadır. Ancak küresel sorunlar kişisel sorun ölçeğine indirgenmektedir. Geç kapitalist dönemde küresel sorunların aşılması noktasında bireyin kendisinin sorunları aşabileceği iddia edilecektir. Birey kendine has olan becerisiyle bu sorunları aşabilir, denilmektedir. Geç kapitalist ve geç modern koşulların ortaya çıkardığı sorunlar, belirsizlikler ve açmazlar kişisel sorun ya da başarı-başarısızlık ölçeğine dayandırılarak açıklanmaktadır.

\section{Televizyon Dizilerinin Yansıttığı Özellikler: Dizi Gerçekliği}

Türkiye'de televizyon dizilerinin izlenmesi, insanların çoğu kez akşamları toplanarak gerçekleştirdikleri günlük bir etkinlik halini almaktadır. Özellikle dizilerin, televizyon 
programları içinde en yaygın olarak izlenilen programları oluşturduğunu da belirtmek gerekir. "Yerli diziler, televizyonun en çok izlenen yapımları arasında yer almaktadır. Bugün önemli yerli televizyon kanallarının en çok izlenen zaman dilimlerine, başka bir deyişle ana yayın kuşağına (20.00-23.00) baktığımızda, yerli dizilerin çoğunlukta olduğunu söyleyebiliriz." (Özsoy, 2011, s. 22). Televizyon dizilerinin, günlük hayatımızda etkin bir yeri olduğunu, dizi izlemenin günlük bir nevi ritüel halini aldığını söylemek gerekir. "Dolayısıyla televizyon aile ve ev kültürümüzün bir parçasıdır.” (Mutlu, 1999, s.104). Bunun yanında, internet aracıllğıyla bilgisayar ve cep telefonu üzerinden televizyon ve dizi izleme imkanının yaygınlaşmasının, günün her saati televizyonun ve dizilerin izlenme alanının genişlemesine katkı yaptığını belirtmek mümkündür. Hatta sadece internet üzerinden izlenilen dizilerin de olduğu görülmektedir. Cheviron’a (2013) göre, her ne kadar televizyonun etkileri günümüzde internet ile değişime uğrasa da "...televizyonun yarattığı görsel ve biçimsel kodların egemenliğinin televizyon/internet birlikteliğiyle arttığı da bir o kadar doğrudur.” (2013, s.17). Cheviron (2013, s. 17-21) televizyon ve internet/televizyon birlikteliğinde ortaya çıkan gerçeklik, sahtelik sorununa eğilir. Televizyonun içinde yaşanılan toplumsal koşulları algılama biçimine olan katkısını vurguladığı görülür.

Televizyon ve özellikle de televizyon dizileri yaygın olarak izlenilen dolayısıyla da içeriklerinden ve imgelerinden fazlasıyla etkilenilen bir yeniden üretim tarzı olarak nitelenebilir. "Kültür endüstrisinin her tezahürü kaçınılmaz olarak insanları, bütünün onları dönüştürdüğü biçimde yeniden üretir." (Adorno ve Horkheimer, 2014, s.171).

Toplumu ve insanları yeniden üretmek dizilerde gerçeklik iddiasıyla ortaya çımaktadır. Diziler; kurgu ve gerçekliğin farklı ölçülerde bir araya gelmesinden oluşmuş bir yapıya sahiptirler. Bununla birlikte, diziler gerçeklik iddiası taşımaktadırlar. Bu nedenle, dizilerde aktarılan unsurların özelliklerine bakılması gerekmektedir. Diziler, koşulları yeniden üretirken, yaşanan gerçekliğin birer aktarıcısı, yansıtııısı oldukları iddiasıyla karşımıza çımaktadırlar. "İknayı tetiklemek için hem görsel hem de işitsel tüm teknik imkânlar kullanılarak, dış dünyanın dolayımlanmadan birebir yansıtıldığı sanısı yaratılmaktadır." (Otan, 2014, s. 14). Örneğin, birçok dizinin çekimde kullandığı mekanlar çoğu zaman herkesin kullandığı, önünden geçtiği yerler olabilmektedir. Çoğunlukla İstanbul'un önemli merkezleri ve noktaları bu açıdan kullanılmaktadır. Boğaz Köprüsü, yeni açılan alışveriş merkezleri, İstanbul'dan bir vapurun görüntüsü veya Kız Kulesi’nin görüntüsü çok sık dizilerde görülen ve gerçekliğe vurgu yapan unsurlar olarak karşımıza çımaktadır. Dolayısıyla dizi gerçekliği, gerçek mekânsal unsurların kullanımıyla, söylemlerle yaşanan gerçeklik olduğu iddiasını tekrarlamakta ve yeniden üretmektedir. Dizi gerçekliği olarak ifade edilebilecek unsurların belli özellikleri söylemsel düzeyde şöyle örneklendirilebilir. Yeni bir dizi tanıtımında söylenilenler çoğunlukla; "hepimiz kendimizden bir şeyler bulabileceğiz", "bizden hikâyeler", "kendimizi anlattık" gibi tanımlamalar yer almaktadır. Dizilerde gerçeklik vurgusu farklı unsurların kullanımı ile gerçekleşmektedir. 
"Film, gündelik algı dünyasını yeniden vermeyi amaçladığı için, dışarıdaki sokakları az önce izlediği filmin devamı olarak algılayan sinema izleyicisinin bu bildik deneyimi yapımın temel ilkesi haline gelmiştir. Yapım teknikleri, ampirik nesneleri ne kadar yoğun ve eksiksiz kopyalayabilirse, dışarıdaki dünyanın beyazperdede gösterilenin kesintisiz bir uzantısı olduğu yanılsamasını yaratmak da o kadar kolay olur." (Adorno ve Horkheimer, 2014, s.169).

Bunların yanı sıra, dizilerin gerçeklik iddiasını destekleyen bir diğer unsur da dizilerin sürekliliğidir. Diziler, süreklilik bakımından ise, düzenli bir periyotta yayınlanmaktadırlar. Hatta bazı diziler yıllar boyu sürebilmektedir. “...yakınlık duygusu, yine televizyonun özelliği olan süreklilik ve zamana yayılma olanakları ile daha da güçlenir. Süreklilik, yakınlık ve içtenlik duygusunun daha derin bir şekilde gelişmesini sağlayarak, izleyicilere etkili bir yoğunluk duygusu sağlar. Böylece izleyicilerle etkili bir ilişkinin kurulduğundan söz edilebilir." (İlhan, 2014, s. 92).

Buna ek olarak dizilerin, süreklilik özelliklerini ve inandırıcılık özelliklerini kullanarak gerçeklik iddiasını vurgulamaları ve bu sayede gerçekliği yeniden ürettikleri görülür. Poyraz’’n (2002) da dediği gibi televizyon “... tüm program türleriyle her eve ortak bir imaj ve iletiler dünyası getirir. Diğer bir boyutu ile günümüz insanı, televizyonun simgesel dünyası içinde doğar; ve televizyonun tekrarlanan pratiği ile yaşar. Televizyon tutum ve davranışları eker.” (2002, s. 23).

Televizyon dizilerinde, izleyicilerin gerçekliğe bakışını etkileyen öğelerden bir diğeri de Ien Ang'ın Dallas dizisi üzerine yaptığı araştırma ile vurgulanmıştır. Ien Ang, 1980'li yıllarda Dallas dizisinin elde ettiği uluslararası başarıyı ortaya koymak amacıyla bir araştırma gerçekleştirmiştir. Bir dergiye ilan vererek, Dallas dizisini neden sevip, izlediklerini ve neden sevmediklerini insanların kendisine açıklamalarını istemiştir. Kendisine gelen mektupları inceleyerek Dallas dizisiyle ilgili değerlendirmelerde bulunmuştur (Storey, 2000, s. 27).

“Ang'e yazanlara göre, Dallas'tan zevk alma ya da almama olayı, gerçekçilik meselesi ile ayrılmaz bir şekilde bağlantılıdır. Yine, bir programın 'iyi' ya da 'kötü’ bulunmasının ölçütü de, onların programı 'gerçekçi' (iyi) ya da 'gerçekçi olmayan' (kötü) olarak değerlendirmesi ile ilgilidir.” (Storey, 2000, s. 27).

İzleyiciler açısından gerçekliği ortaya koyan özellik ise, anlatılan öykünün iyi ya da kötü olarak tanımlanmasıdır.

Aslında, gerçeklik dışı ve kurgu, kitle iletişim aracılığıyla fazlasıyla kullanılmaktadır. Ancak, televizyon dizileri inandırıcılık açısından değerlendirildiğinde; diziler, gerçeklik dışı öğelerin kullanımı bakımından oldukça yoksun özellikler göstermektedirler. Televizyon dizilerinde amaçlanan inandırıcılık ve gerçekçiliktir. Bu nedenle oyunculuk önemsen konuların başında gelmektedir. Bu anlamda, bir dizi gerçekliğinin yaratılmaya çalışıldığı rahatlıkla söylenebilir. Dizilerin inandırıcılık ve süreklilik unsurlarını kullanarak yarattığı bu gerçeklik, toplumsal gerçekliğin kendisi gibi algılanması sorununu ortaya çıkarmaktadır. “....dış yaşam gerçekliği ile 
kitlelerin arasında duran televizyon, anlamlandırma sürecinde etkili bir rol oynamaktadır." (Otan, 2014, s.28). Yoğun bir şekilde dizilerin aktardığı düşünce ve yaklaşım tarzlarının insanları etkilediği belirtilmelidir.

Postman da televizyonun insanı etkilediğini ve hatta insanın bilme yollarını etkilediğini vurgulamaktadır. Postman'a (2014, s. 92) göre, “Televizyon 'üst-araç' (meta-medium) statüsüne; yalnızca dünyaya ilişkin bilgimizi değil, aynı zamanda bilme yollarına ilişkin bilgimizi de yönlendiren bir araç statüsüne yükselmiştir." Bu nedenle televizyon ve yeni türevleri aracllğııla aktarılan bilgiler, imajlar incelenmeli ve toplumsal sonuçları değerlendirilmelidir. Postman (2014, s. 93) televizyonun bize bilgi ve gerçeklik bakımından, doğruluğunu sınamadığımız, doğal olarak kabul ettiğimiz bir süreç olarak geldiğini vurgulamaktadır. Fiske (2014) de televizyonun bir gerçeklik ürettiğini vurgulamakta ve bu gerçekliğin kapitalizmle olan ilişkisini dile getirmektedir.

“...televizyon, endüstriyel sistemin ekonomik alanda yaptığını göstergebilimsel alanda yapar. Endüstriyel sistem yalnızca mal üretimi ve yeniden üretimi yapmaz: son kertede ve kaçınılmaz olarak yeniden ürettiği şey kapitalizmin kendisidir. Televizyon da, telegörsel gerçeklik üretimi sırasında nesnel gerçekliği değil, kapitalizmi yeniden üretir." (Fiske, 2014, s.30)

Dizi gerçekliği ile yaratılan ve yeniden üretilen gerçeklik insanların birebir yaşamı olarak algılanmaktadır. Baudrillard'ın $(2018,2016)$ iletişim araçları sayesinde topluma aktarılan gerçekliğe dair çözümlemesine dizi gerçekliği bağlamında da bakılabilir. Baudrillard (2018, 2016) içinde yaşanan dünyada gerçekliğin, iletişim araçları aracilığıyla gerçeğine çok benzeyen özelliklere sahip fakat gerçekliğin kendisi olmayan, onun bir simülasyonunu izlediğimiz/yaşadığımız iddiasında bulunmaktadır. Bu bağlamda, kitle iletişim kültürüyle topluma yansıtılan her temsilin gerçekliğin farklılaşmış birer kopyaları olduğunu yani sözde olay/yeni gerçeklik olduğunu vurgulamaktadır (Baudrillard, 2016, s. 159-160). "Gerçeklik, aracın kendisi tarafından gerçekleştirilmiş modelin bu yeni gerçekliğinin yararına yok edilir, buharlaştırılır." (Baudrillard, 2016, s. 160). Baudrillard (2018, s.76-80) televizyonun, yaşanan bir olayı ele aldığı ve dizi haline getirdiği örneklerde bile gerçekliğin anlamının, öneminin ve derinliğinin yitirilmesini, toplumun gözünde olayın önemsiz bir mesele haline gelmesini sağladığını düşünmektedir. Önemli bir olayda bile, olayın televizyon dizisi haline gelmesiyle, o olayın yol açacağı toplumu etkileme potansiyelini televizyonun ortadan kaldırdığını vurgulamaktadır. Baudrillard'a göre televizyon imgesi zihinde gerçek etkileyiciliği üretememektedir. Aslında, Baudrillard’a göre (2018, s. 79-80) televizyon dizisi gerçekliğin anlam yitimini beraberinde getirmektedir. Televizyon dizilerinde gerçeğin yerine ona çok benzeyen ancak ondan başka bir şeyi onun yerine koyarak gerçekliğin anlamı kaybolmaktadır. Ayrıca bu noktada Baudrillard (2016, s.122-126) kültürel yeniden çevrim ile simülasyonu da ilişkilendirmiştir. Kültürel ürünlerin gerçek değerinden öte, tüketim piyasası için güncel hale getirilmesi, hatırlatılması, çoğalması işlevini yerine getiren kültürel çevrimdir. Kültürel çevrim sadece kültürel ürünlerle sınırlı değildir. Bilim, teknik gibi alanlarda olabildiği gibi kariyer alanlarında da güncelliği takip etme gerekliliği olarak kendini gösterir (Baudrillard, 2016, s.122- 
126). Bunlara ek olarak, Giddens'ın modernizm ve medya konusunda bahsettiklerini de konuyla ilişkilendirmek gerekli görünmektedir. Giddens, (2014, s.43) televizyon, film ve videonun görsel imgeler olarak basılı metinlerden daha farklı yapılar ortaya koyduğunu belirtmektedir. Giddens, modernizmin yerinden-çıkarıcı ve küreselleştirici etkilerini vurgulamaktadır. Giddens, (2014, s.33) yerinden-çıkarma kavramını, toplumsal ilişkilerin bağlamlarından kopartılması ve zamansal-mekansal açıdan tekrar bir araya getirilmesi olarak nitelemektedir. Modernizmin neden olduğu zamansal-mekansal uzaklaşmadaki hızlanmanın nedenini toplumsal ilişkilerin bağlamlarından kopartılması olarak açıklamakta ve kavramsal olarak yerinden-çıkarma deyimiyle nitelemektedir. Giddens, (2014) geç kapitalist ve modern koşullarda televizyon ile toplumsal bağlamlarından kopmuş gerçekliklerin üretildiğini ifade etmektedir.

Televizyon dizileriyle yeniden üretilen toplumsal gerçekliğe, başarı ve başarısızlık bağlamında bakmak gerekmektedir. Aliye dizisi, başarı kavramını yansıtmak bakımından nasıl bir dizi gerçekliği ortaya koymaktadır?

\section{Örneklem Seçimi ve Yöntem}

Çalışmada “Aliye” dizisinin ilk 28 bölümünden örneklem olarak yararlanılmıştır. Dizinin konusu içinde farklı hikayeler ${ }^{3}$ iç içe geçmekle birlikte, dizinin bütün olay örgüsü makalenin örneklemi oluşturmamaktadır. Sadece esas karakter olan Aliye'nin iş yaşamına atılması ve iş yaşamının gelişimi süreci örneklem olay örgüsü olarak belirlenmiştir. Çalışmanın amacı başarı konusunun dizide nasıl sunulduğunu ele almak ve tartışmak olduğu için böyle bir sınırlamaya gidilmiştir. Çalışmada dizinin başarı konusunu nasıl sunduğunu eleştirel söylem çözümlemesi açısından ele almak amaçlanmaktadır. Yöntem tercihinde, dizide anlatılan başarının hangi bağlamda ele alındığını sosyolojik açıdan değerlendirebilmek ve açıklayabilmek açısından eleştirel söylem çözümlemesi tercih edilmiştir. Eleştirel söylem çözümlemesinde özellikle disiplinler arası bir biçimde meseleye yaklaşmak ve toplumsal, kültürel bağlam içinde eleştirel söylem çözümlemesinde bulunmak önem taşıdığı için bu yöntem uygulanmıştır. Fairclough'un eleştirel söylem çözümlemesi yöntemiyle dizi incelenmiştir. “Söylemler esas olarak sabitlenmiş toplumsal yaşamın farklı temsilleridir -farklı olarak konumlandırılmış toplumsal aktörler toplumsal yaşamı değişik şekillerde ve değişik söylemlerde «görür» ve temsil eder.” (Fairclough, 2015, s. 138). Dizideki başarı sunumunun ele alınışında dizinin öyküsünü anlatan metnin anlamını ele almanın yanı sıra içinde yaşanılan küresel iktisadi üretim ve tüketim ilişkileriyle, yani kapitalist aşamanın dönüşümleriyle ilişkilendirmek amaçlanmaktadır. Dolayısıyla dizi analiz edilirken sosyolojik, eleştirel bir yaklaşımla ele alındığı belirtilmelidir.

Bu çalışmada, Aliye dizisindeki verilerden hareketle dizideki başarı sunumu ele alınmış ve dönemin özellikleriyle ilişkilendirilmeye çalışılmıştır. Aliye dizisinde başarının kişisel yeteneğe indirgendiği gözlenmektedir. Bu dizi özelinde ortaya çıkan verileri geç kapitalist dönemin özellikleriyle ilişkilendirmek mümkün olmuştur. Ancak bu çalışmanın geçerliliği çalışmanın sınırlarını oluşturan Aliye dizisiyle sınırlıdır. $\mathrm{Bu}$ açıdan makalenin bulgularının

\footnotetext{
${ }^{3}$ Çocuklarının velayetini edinme ve onlarla bir araya gelme çabası, komşularla yeni dostluklar kurma, avukatının tacizine uğrama.... vs. gibi 
genellenebilirliği söz konusu değildir. Farklı pek çok dizinin analiz edildiği başka çalışmalarla ancak genellenerek başarının kişisel yeteneğe indirgenmesi yaklaşımının dizilerdeki söylemlerde genel bir eğilim olup olmadığı yönünde değerlendirmelerde bulunulabilir.

\section{Aliye Dizisinin Konusu}

“Aliye” (2004) dizisine bakıldığında, Aliye karakteri dizinin başında Edirne’de yaşayan bir ev hanımıdır. Eşinin ailesi varlıklı ve tanınan bir ailedir. Ev hanımı iken bir terzi değildir ama kendi elbisesinin çizimlerini yapan bir kişidir. Ailevi sorunlardan dolayı eşinden boşanmak isteyecektir. İstanbul'a dayısının yanına gelip, yerleşecek ve yeni bir hayat kurmaya çalışacaktır. Aliye, İstanbul'a gelirken çocuklarından birini kocası kaçırmıştır. Edirne'de kalan kızını geri almak onun en önemli isteğidir. Aliye, dayısının yeni komşuları tarafından çok sevilen bir kişidir. Aliye, iş ararken gazetede bir ilan görür. Yetiştirilmek üzere butikte çalışacak eleman aranmaktadır. Dikişten anladığı için moda evine gider ve burada işe başlar. Moda evi birkaç çalışanın olduğu ve modacı Valentino Naci Bey'in kurduğu bir işletmedir. Burası seri üretim bir giyim mağazası değil, özel dikim yapan bir moda evidir. Aliye karakteri çok kısa bir zaman dilimi içerisinde işe girdiği moda evini yöneten konuma geçmekte ve ardından da defileleri başarılı olan bir tasarımcı haline gelmektedir.

\section{Bulgular ve Değerlendirme: Başarı Hikâyesi}

Dizide, Aliye'nin iş yaşamıyla sınırlandırılmış olay örgüsünden ortaya çıkan bulgular özellikle toplumsal yaşamda, iş yaşamında başarılı olmanın süreçlerinin nasıl açıklandığı ile ilgilidir. Bulgularda, Aliye'nin iş yaşamında başarıyı kolaylıkla elde ettiği ortaya çıkmaktadır. Kişiye özel bir biçimde Aliye'nin sahip olduğu özelliklere -yeteneğe- vurgu yapılarak iş yaşamında başarılı olmanın açıklandığı görülmektedir. Kişisel özellikler başarıda belirleyici nitelik olarak açıklanmaktadır. Dolayısıyla deneyim, bilgi birikimi, emek ve zaman gibi toplumsal bağlamların yerine kişisel yetenek başarının ortaya çıkmasında belirleyici temel etmen olarak söylemsel düzeyde vurgulandığı görülmektedir. Aliye deneyim, bilgi birikimi gibi toplumsal süreçsel özelliklere sahip olmamakla birlikte iş yerinde yetkileri artmakta ve sürekli hızlı bir yükseliş göstermektedir. Dizideki söylemde, bir başarının ortaya çıkışında bireysel koşullar, toplumsal bağlamdan daha önemli ve daha belirleyici olarak sunulmaktadır. Eleştirel söylem çözümlemesi yöntemiyle dizideki başarı söylemi ele alınarak aşağıda ayrıntılı olarak analiz edilmiştir.

Dizide üçüncü bölümde Aliye gazete ilanında, moda evine yetiştirilmek üzere bayan eleman aranıyor şeklinde bir ilan görür. Aliye iş ilanı için görüşmeye moda evine gider.

Üçüncü bölüm:

"Süheyla: Buyrun efendim hoş geldiniz.

Naci: Hoş geldiniz.

Aliye: Hoş bulduk

Süheyla: Buyrun şöyle...

Naci: Kim dikti üzerinizdekini, kupu çok güzelmiş...

Aliye: Aile terzimiz 
Naci: Öyle mi kimdir?

Aliye: Tanımazsinız Edirne'de...

Naci: Bravo güzel oturtmuş, size de çok yakışmış hanımefendi.

Aliye: Sağ olun.

Naci: Ben nasıl yardımcı olayım size? Tayyör, döpiyes, belki bir gece elbisesi...

Aliye: Yok. Ben iş ilanı için gelmiştim.

Naci: Ne işi.

Aliye: Moda evinde yetiștirilmek üzere bayan eleman aranıyor diye ilan vermişsiniz.

Süheyla: Ah...Biz o iş için eleman aldık.

Aliye: Öyle mi, geç kaldım demek.

Süheyla: Keşke bir telefon etseydiniz önce buraya kadar zahmet etmezdiniz.

Aliye: Olsun, hiç önemli değil. Teşekkür ederim rahatsız ettim.

Naci: Bir dakika bir dakika...

Aliye: Buyrun.

Naci: Dikişten anlar misiniz?

Aliye: Terzi sayllmam ama anlarım. Ben klyafetlerimin modellerini kendim çizerim.

Naci: Üstünüzdekini de siz mi çizdiniz?

Aliye: Evet.

Naci: İşariyorsunuz öyle mi?

Aliye: Evet.

Süheyla: Ama Naci Bey...

Naci: Bir konuşalım bakalım."(Aliye, 2004).

Moda evinde yetiştirilmek üzere bir eleman aranmaktadır. Hatta işe bir kişi alınmıştır. Fakat Aliye'nin üzerindeki elbise sıradan bir elbise değildir. Elbise, dikişi açısından modacı olan Naci Bey’in dikkatini çekmiştir. Naci Bey, dikişi maharet gerektiren bir elbise olduğunu düşünür. "Kim dikti üzerinizdekini..." "Bıravo güzel oturtmuş..." ifadelerinden anlaşılmaktadır. Naci Bey elbisenin terzisini merak etmektedir. Edirne'den bir terzi elbiseyi dikmiştir. Ancak Aliye bütün elbiselerinin çizimini kendi yaptığını belirtir. Naci Bey'in Aliye'yi işe almasında bu elbisenin etkili olduğu görülür. Ayrıca işe alınırken yetiştirilmek üzere bir eleman olarak Aliye işe alınmıştır. Fakat ilerleyen bölümlerde Aliye'nin moda evinde eğitimden geçirildiğii bir sahne söz konusu değildir.

Dokuzuncu bölüm:

"Aliye: Şurası bir șey istiyor sanki değil mi? Şuraları da biraz toplayalım? Ne dersiniz? Selin: Ay... çok doğru. Sizin adınız ne?

Aliye: Aliye.

Selin: Aliye Hanım inanamıyorum bu elbise başka bir şey oldu. Ayy ne kadar marifetlisiniz yaa...

Naci: Eee anladın mı şimdi Azade’nin niye başka terziye gitmediğini

Selin: Naci bak söyleyeyim, ben bundan sonra yazllirım buraya, ama her șeyimi Aliye Hanım dikecek ona göre.

Naci: Bana söyleme Aliye'ye söyle eli sihirli olan o." (Aliye, 2004). 
Selin biraz sorunlu bir müşteridir. Başka bir terzide diktirdiği ve beğenmediği elbiseyi Naci Bey'e getirir. Elbisenin düzeltilmesini istemektedir. Naci Bey, Aliye ile birlikte elbisede ne gibi değişiklikler yapabileceklerini düşünürler. Aliye'nin elbisede yaptığı düzeltmeler müşteri tarafından çok beğenilir. Naci Bey müşterinin sorununu çözemezse, zaten daha önce başka bir terziye giden müşteriyi bundan sonra tamamen kaybedecektir. Ancak bu sorunu Aliye'nin önerdiği tadilatlar çözmüştür. Selin elbisenin yeni halini çok beğenir. Karşılaşılan sorunun çözülmesinde Aliye'nin fikirleri etkili olmuştur. Ayrıca Selin, Aliye’yi çok yetenekli bulur. Selin artık her dikişini Aliye'nin yapmasını istemektedir. Naci Bey’in gözünde de Aliye dikiş konusunda becerikli, dikişe ait sorunları çözebilen âdeta eli sihirli yani diğer kişilerden farklı bir biçimde, az kişiye nasip olacak şekilde yeteneği olan biri gibi görülmektedir. “...eli sihirli olan o." ifadesinden ve metnin bütününden anlaşılmaktadır. Aliye'nin özelde sahip olduğu özelliklere gönderme yapılmaktadır.

Dizide on birinci bölümde, moda evinde çalışan Süheyla ile Çimen arasında şöyle bir konuşma geçmektedir.

"Süheyla: Hayret bir şey yaaa... Dă̆daki geldi bă̆dakini kovacak nerdeyse.

Çimen: Ne oldu Süheyla abla?

Süheyla: Kuş kondurmuş hanımefendi bir gülmeler kırıtmalar. Tam 16 yıldır burada

çalışıyorum şu kadının bir günde aldığı iltifatı almadım daha!

Çimen: Aliye abladan mı bahsediyorsun?” (Aliye, 2004).

Bu sahnede olan konuşma, ilk bakışta çalışanlar arası (Süheyla-Aliye) çatışma, gerilim ya da Aliye’nin, Süheyla tarafından kıskanılması gibi görünmekle birlikte başka bir meseleyi de açığa vuran bir konuşmadır. Bir tarafta 16 yıldır bu moda evinde çalışan deneyimli bir eleman, bir diğer tarafta da yetiştirilmek üzere alınarak, yeni işe girmiş, deneyimi olmayan fakat moda evinin karşılaştığı sorunlar karşısında sorunları aşmakta faydası olacak şekilde dikiş konusunda bir yetenek sahibi olduğu anlatılmak istenilen Aliye karakteri söz konusudur. Süheyla'nın ifadelerinden kıskandığı anlaşılmaktadır. Fakat bundan daha önemlisi toplumsal bağlam açısından ortaya çıkan anlam daha değerlidir. Bir işte deneyim, bilgi birikimi ve zamanını bir işe vermek, yetenek gibi bir konunun önceliğine karşı göz ardı edilebilen bir değer taşımakta olduğu anlaşılmaktadır.

On üçüncü bölüm:

"Aliye: Bir iki şal koyalım diyorum Selin Hanım

Naci: Çok iyi fikir. Refiye Hanım da el işi yapar üstüne

Selin: Aliye... Lütfen bana Selin de, sen benim imaj makerımsın artık

Aliye: Nasil istersen.

Naci: Sil beni defterden sil, aferin.

Selin: Senin yerin ayr Naci siler miyim hiç.

Naci: Bir imaj maker olamadim ama

Süheyla: Bundan kaç top ısmarlayayım Naci Bey.

Naci: Íster miyiz bundan artık bilmem ki. Ne dersin Aliye? 
Aliye: Süheyla daha iyi bilir Naci Bey.

Naci: Sen karar ver Süheyla.

Süheyla: iki top istiyorum o zaman.

Selin: Gazeteciler falan sorarlarsa Aliye'nin adını verebilirim değil mi? Kostüm tasarımcısı olarak.

Naci: Tabi ama Valentino Naci Moda Evini de unutma” (Aliye, 2004).

Bu sahnede ilk başta Naci Bey, Aliye ve Selin moda evinde oturup konuşmaktadırlar. Selin'in kıyafetleriyle Naci Bey değil, artık Aliye ilgilenmektedir. Selin, Aliye’ye artık dikiş konusunda fazlasıyla güvenmekte, kıyafet konusunda kendi tasarımcısının Aliye olduğunu belirtmektedir. Daha sonra sahneye Süheyla girerek Naci Bey’e bir kumaş getirir, kaç top bu kumaştan ısmarlanması gerektiğini sorar. Naci Bey moda evini tek başına kendisi yönetmesine ve deneyimli olacağı -ellili yaşlarda bir kişidir- tahmin edilebilecek bir moda evi sahibi olmasına rağmen kumaş alımı konusunda Aliye’ye danışır. Aliye, Süheyla karar versin demiştir. Süheyla ne kadar alınacağına karar verir, fakat Naci Bey'in kendi başına karar almayı tercih etmek yerine Aliye'ye sorma gereği duyması dikkate çekicidir. Aliye'nin Naci Bey üzerinde ve dolayısıyla moda evinde alınan kararlarda otoritesinin arttığının bir göstergesidir. Giderek Aliye'nin moda evinde konumunun yükseldiğinin işaretleri görülmektedir. Naci Bey bile ona danışma gereği duymaktadır. Ayrıca Selin, kıyafetlerini soran kişilere Aliye'yi kendi kostüm tasarımcısı olarak tanıtmak istemektedir. Naci Bey'e göre, Valentino Naci Moda Evi diye vurguladıktan sonra Aliye'nin tasarımcı olarak ifade edilmesinden memnundur. Ayrıca yetiştirilmek üzere işe alınan Aliye moda evinde kostüm tasarımcısı haline gelmiştir. Bir önceki sahnede 16 yıldır çalışan Süheyla’nın deneyimi ve birikimi üzerinden, deneyimin, bilgi birikiminin yetenek karşısında geride kalması ortaya çıkmıştı. Bu sahnede ise, modacı Naci Bey'in deneyimi ve bilgi birikimi dahi, Aliye'nin yeteneği karşısında daha geride kalmakta, Naci Bey moda evine dair konularda Aliye’ye danışma gereği duymaktadır.

Yetenek; iş yaşamında imkanlar elde etmek, yükselmek, aynı zamanda moda evi açısından da, bir işletme olarak yeni müşteriler kazanılmasına, gelirin arttırmasına imkan verdiği ölçüde önemsenen bir konu haline gelmiştir. Deneyim sahibi olmak, bilgi birikimine sahip olmak, emek vermiş olmak toplumsal yaşamın gelişiminde bir değer olmaktan uzaklaşmaya başlamaktadır. Çünkü deneyim, bilgi birikimi, emek bu koşullarda başarıyı beraberinde getirmemektedir. Selin ile olan konuşmasında Naci Bey bile bir tasarımcı olamadığını şaka yoluyla ifade ederek bu gerçeği dillendirmektedir. ${ }^{4}$ Kısa sürede fayda sağlayan özellikler toplum yaşamında daha önemli hale gelmektedirler.

On üçüncü bölüm:

"Naci: Arkadaşlar Aliye Hanım artık moda evinin tasarımcısı, bazı özel müşterileri de ona veriyoruz. Mesela Selin'i

Aliye: Ama Naci Bey

${ }^{4}$ Naci Bey çok kibar bir biçimde şakaya vurarak ifade edecektir. Naci Bey'in deneyimi, bilgi birikimi, tanınırlığı, moda evi sahipliği dahi onu bir tasarımcı haline getirememiştir. 
Naci: Tabi yine Valentino Naci Moda evi için çalışacak. Ama Selin'le o muhatap olacak.

Süheyla: Pardon anlamadım. Ne demek şimdi bu?

Naci: Bir şey demek değil Süheyla. Selin hanım Aliye hanımın özel bir müşterisi yani.

Selin'i ikna etmek, ona model seçmek Aliye'nin işi

Süheyla: Eee...

Naci: Eeesi... onun işi çok onu ıvır zıvır işlerle meşgul etmesek iyi olur.

Süheyla: Bizim elimiz boş öyle mi?

Naci: Öyle bir şey demedim Süheyla, aslında değişen bir şey yok. Her şey yine eskisi gibi.

Süheyla: Peki bu tasarımcı lafı nerden çıktı.

Naci: Bu işler eskisi gibi değil Süheyla, böyle dergilerden model yürüterek devam edemeyiz değil mi? Biraz böyle kreatif olmak lazım.

Süheyla: İyi de niye Aliye?

Naci: Çünkü ben öyle uygun gördüm bir sakıncası mı var?

Süheyla: Siz daha iyi bilirsiniz tabi." (Aliye, 2004).

Bu sahne moda evinde geçmektedir. Naci Bey bütün çalışanları toplamıştır ve bir açıklama yapmaktadır. Aliye'nin tasarımcı olarak artık moda evinde çalışacağını duyurmaktadır. Çalışanlar arasında tepkiyi yine Süheyla vermektedir. Aliye'nin yetiştirilmek üzere bir eleman olarak işe alınmasından sonra, bir tasarımcı haline gelişi süreci çok hızlı gerçekleşmektedir. Süheyla moda evinden birinin tasarımcı olmasına değil, neden Aliye'nin seçildiğine tepki vermektedir. Deneyim sahibi bir çalışan olan Süheyla’nın kıskançlık duygusunun özellikle dizide altının çizildiği bir diğer önemli meseledir. Önceki bir sahnede de ilk bakışta, Süheyla’nın kıskançlığını anlatan bir konuşma vardır. Süheyla'nın içinde yer aldığı sahnelerde ağırlıklı olarak Süheyla'nın başka özelliklerinden öte kıskançlığının açığa çıktığı davranışlar dizide yansitılmaktadır. Süheyla, Aliye'nin tasarımcı olmasına itiraz etmekte fakat Naci Bey'in otoritesi karşısında geri adım atmaktadır. Ayrıca, Naci Bey konuşurken; "Bu işler eskisi gibi değil, Süheyla...” diyerek artık iş yaşamında koşulların değiştiğinin altını çizmektedir.

On dördüncü bölüm:

"Naci: Aliye... al şunu, ellerine sağlık.

Aliye: Nedir bu Naci Bey

Naci: Selin'in sahne kostümlerini yaptın ya, onun bedeli

Aliye: İyi de bu fazla değil mi?

Naci: Az bile bu işleri hiç bilmiyorsun. Bak Aliye senin müthiş bir guston var. Allah vergisi bir yeteneğin var. Şık şık iki hareket yapıyorsun. Elbisenin ruhu değişiyor. Eee bunun da bir bedeli var tabi. O da bu zarfta işte.

Aliye: Hakkım mı bu şimdi?

Naci: Gül hakkın hem de, elinin emeğinin göz nurunun hakkı. Güle güle harca.

Aliye: Teşekkür ederim.

Naci: Rica ederim." (Aliye, 2004). 
Bu sahnede Naci Bey ve Aliye bulunmaktadırlar. Naci Bey Aliye’ye içinde para olan bir zarf vermektedir. Aliye şaşırır. Naci Bey bu parayı onun hak ettiğini belirtir. "... Aliye senin müthiş bir guston var. Allah vergisi bir yeteneğin var.” Onun sahip olduğu kişisel yetenek vurgulanarak, tekrar gündem gelmekte ve parayı hak etmesinin nedeni olarak açıklanmaktadır. Ayrıca Aliye'nin dikiş konusundaki yeteneğinin, dikiş bilgisi temelli olmadığı sanki farklı bir şey olduğu “... Şık şık iki hareket yapıyorsun. Elbisenin ruhu değişiyor ..." ifadesinden anlaşılmaktadır. Herkesin anlamadığı ama Aliye’ye özgü bir şekilde, elbise üzerinde yapılan işlemler o nesneye bambaşka bir özellik kazandırmaktadır. Kişisel olarak ona özgü, sadece onun sahip olduğu özellikler neticesinde Aliye'nin başarıyı elde etmiş olduğu anlamı verilmek istenilmektedir. Bu noktada kişiye özgü özelliklere sahip olmak bir nevi şans anlamını da içinde barındırmaktadır. Herkese nasip olmayan bu özellik Aliye'de mevcuttur. Başarı, kişilerin sahip oldukları belli yeteneklerle ve şans eseri bir biçimde bazı kişilerde olan özelliklerle ortaya çıkabilir, anlamı dizide sunulmaktadır. Eğer bu özel yeteneğe sahipseniz başarı çok kısa sürede elde edilebilir. $\mathrm{Bu}$ açıdan başarı toplumsal yaşamda belli yeteneklere sahipseniz elde edebileceğiniz bir firsattır. Ancak bu yetenek eğitim, bilgi birikimi temelinde ortaya çıkan bir yetenek de değildir. Kişiye özel bir yetenektir. Aliye bu açıdan diğer insanlardan farklıdır. Başarı, bu farklılıklara sahip, kişiye özgü yeteneklere sahip kişilerin elde edebileceği bir imkân olarak yansıtılmaktadır. Yukarıdaki diyalog ile olay örgüsüne $e^{5}$ bütünsel olarak bakıldığında bu anlatımdan ortaya çıkan anlam: Başarı, çalışan, bilgi birikimi olan, bir işe zaman harcayarak uzun süre emek veren herkese açık değildir. Bu anlamda toplumda diğer insanlardan farklı olan, belli yeteneklere sahip olanlara açık olan imkânlar ve fırsatlar vardır.

\section{On dokuzuncu bölüm:}

"Refiye: Hoş geldin

Naci: Hoş geldin

Aliye: Günaydın. Geç kaldım Naci Bey kusura bakmayın faturaları yatırmak için

Naci: Bırak şimdi faturayı... sana müthiş bir haberim var.

Aliye: Hayrola

Naci: Geçen hafta bir tekstil firmasına senin modellerini göstermiştim ya

Aliye: Evet

Naci: Bizim atölyede seri üretim istiyorlar.

Refiye: Bu iyi bir şey değil mi Naci Bey?

Naci: Ne demek Refiye Hanım iyi olmaz mı? Harika bir şey... Aliye'nin modellerini satın alacaklar. Hiç beklemiyordum bu kadara çabuk ilgileneceklerini. Seninle mutlaka tanışmak istiyorlar. Cenk Bey sabahleyin cebimden aradı arabada. Ben de bir havaya girdim ki sorma. Bugün 2 gibi toplantıya buyrun dedim, hem de atölyeyi görürüsünüz dedim." (Aliye, 2004).

Bu sahne atölyede geçmektedir. Moda evinde çalışmaya başlayan Aliye'nin komşusu Refiye, Naci Bey, Çimen oturmaktadırlar, Aliye içeri girer ve konuşmaya başlarlar. Naci Bey’in bir önemli haberi vardır. Bir tekstil firması Aliye’nin modellerini görüp beğenmiştir ve satın almak istemektedir. Naci Bey’in atölyesinde üretilmek üzere seri üretim planlanmaktadır. Firma

\footnotetext{
${ }^{5}$ Aliye'nin iş yaşamıyla sınırlandırılmış olan olay örgüsü kastedilmektedir.
} 
yetkilileri Aliye ile tanışmak ve görüşme yapmak istemektedirler. Naci Bey de görüşme için bir toplantı planlamıştır. Naci Bey, konuşmasında kendisinin de bu kadar zaman içinde modelleri beğeneceklerini beklemediğini belirtmektedir. Bu durum, Naci Bey için de şaşırtıcı olmuştur. Aliye moda evindeki yükselişinin yanında başka bir firmayla birlikte yeni bir iş girişiminde bulunma konusunda da ilerleme kaydetmektedir.

Yirmi dördüncü bölüm:

"Naci: Maşallah işler çok iyi Aliye. Cenk Beyle çok iyi ahbap olduk. Şimdi Almanya'yla ihracat yapacak.

Aliye: Çok sevindim Naci Bey.

Naci: İşlerimiz daha da artacak. Adam senin yeni bir şeyler çalışmanı istiyor.

Aliye: Ne gibi?

Naci: Spor giyim falan. Bir toplantı yaparız. Ayrıntısıyla anlatır. İş çok ciddiye bindi, anlayacă̆ın. Fason atölyesi harıl harıl.

Aliye: Çalışırız Naci Bey merak etmeyin.” (Aliye, 2004).

Aliye'nin modelleriyle seri üretim olarak üretilen ürünler artık yurtdışında satılmaya başlayacaktır. İşler büyümüştür. Üretim yoğun olarak devam etmektedir. Hatta daha da büyümeye devam edecek gibi görünmektedir. Firma, farklı bir giyim tarzında da üretim yapmak isteyerek ürün çeşidini arttırmak istemektedir. Daha yoğun bir çalışma temposu Aliye'yi beklemektedir.

Yirmi altıncı bölüm:

"Naci: Hasta Çocuklara Hayat Vakfı diye bir şey duydun mu?

Aliye: Evet

Naci: Vakıf yararına bir defile yapabilir miyiz diye soruyorlar. Nerden biliyorlar bizi?

Refiye: Her mecmuada buranın adı geçiyor Naci Beycim niye bilmesinler.

Naci: Doğru, ünlü olduk artık. Yapsak mı Aliye?” (Aliye, 2004).

Moda evinde Naci Bey, Refiye ve Aliye defile teklifini değerlendirmektedirler. Defile teklifi ve diğer gelişmeler sonucunda artık herkes tarafından tanınan bir moda evi olduklarını düşünmektedirler.

Yirmi sekizinci bölüm:

"Çimen vd. çalı̧̧anlar: Tebrikler Naci Bey çok şahaneydi.

Naci: Teşekkür ederim hanımlar sizin sayenizde, hepinize çok teşekkür ederim.

Çalışanlar: Rica ederiz.

Naci: Hadi Aliye.

Aliye: Ne oldu?

Aliye: Selama çıkacă̆ız.

Aliye: Biz mi!?

Naci: Hadi hadi.

Aliye: Ben çıkmam, siz çıkın

Naci: Ne demek ben çıkmam bu senin kreasyonun çıkacaksın kızım.

Aliye: Teşekkür ederim Naci Bey ama siz çıkın ne olur. Pek sevmiyorum böyle şeyleri,

hem böyle çıkamam...

Naci: Hadi..." (Aliye, 2004). 
Defilede kıyafetler tanıtılmıştır. Defile sahibinin sahneye gelerek selam vermesi aşaması gelmiştir. Sahne arkasında, Naci Bey ve tüm çalışanlar bir aradadır. Tüm çalışanlar büyük bir sevinçle Naci Bey’i tebrik ederler. Naci Bey, Aliye’ye birlikte sahneye çıarak selam vereceklerini söyler. Aliye hikâyenin bütünü içinde hep iyi niteliklere sahip olarak yansıtılmaktadır. $\mathrm{Bu}$ aşamada da bu tutumu devam eder, Aliye mütevazı davranarak, sahneye çıkmayacağını belirtir. Naci Bey'in çıkmasını istemektedir. Hikâyenin bu aşamasında da, ortaya çıkan başarının Aliye'nin kendi eseri olduğu vurgusu Naci Bey'in ağzından bir kez daha ifade edilmektedir. "Ne demek ben çıkmam bu senin kreasyonun çıkacaksın kızım.”

Toplumsal yaşamda kadının üretime katılması ve sosyal yaşamda yükselmesi bağlamında kadının başarı hikâyesini dizide vurgulamak anlamlı görünmekle birlikte, bu süreci deneyimle, bilgi birikimiyle toplumsal bir sürecin sonunda gerçekleşen bir başarı olarak vurgulamak yerine sadece kişisel yetenekle hızlı bir yükselme süreci olarak açıklanmıştır. Kadının üretime katılması ve iş hayatında yükselmesi toplumsal yaşamda emek, zaman, deneyim, bilgi birikimi ve yoğun bir çaba gerektirmektedir. Bu dizide uzun yıllarını moda evine veren kadın çalışan ya da çalışanlar değil de yeni işe giren Aliye karakteri başarıyı kişisel yeteneğiyle kısa sürede elde etmektedir. Deneyim, bilgi birikimi, zaman faktörlerinin başarıyı elde etmedeki merkezi rolü vurgulanmamış aksine deneyimli diğer kadın çalışanlara rağmen Aliye’nin hızlı yükselişiyle sadece Aliye'nin özelde sahip olduğu özellikler vurgulanmıştır.

Söylemde birinci düzeyde ortaya çıkan anlam, başarının kolaylıkla elde edilebileceğidir. Başarının zor değil, kolay olduğunun dizide altı çizilmektedir. Anlatılmak istenilen başarının kısa sürede elde edilebileceğidir. Dizide aktarılan anlam hayata tutunmanın, iş yaşamında başarılı olmanın kısa sürede mümkün olabileceğidir.

Dizinin söyleminde ikinci düzeyde ortaya çıan anlam ise, yetenekli iseniz toplumsal yaşamda başarılı olmanız mümkündür. Dolayısıyla dizide ortaya konan söylemde ilk ortaya çıkan anlamının altında, bir koşul bulunmaktadır. O koşul da yetenektir. Yetenek herkeste var olan bir özellik midir? Şans eseri bazı insanlarda görülen bir özellik midir? Yetenek görece bir konu mudur? Yani her insan kendini belli bir konuda yetenekli olarak düşünebilir mi? Bu açıdan yetenek muğlak bir kavramı mıdır? Yoksa eğitim aracılığıyla insanda var olan yetenekler açığa mı çıkar? Yetenek gelişebilen bir özellik midir? Yeteneğin gelişebilmesini sağlayan imkanlar toplumsal koşullarda saklı mıdır? Yetenek, hangi koşullarda -şans, genetik ya da imkanlar neticesinde- ortaya çıkmış olursa olsun herkeste olmayan bir özelliktir. Bu açıdan başarı söyleminde, başarı herkese açık değil, yetenekli olana açık bir çerçevededir. Bunun yanında bir diğer konu da, yeni koşullarda kişisel yetenek; deneyim ve bilgi birikiminden daha öncelikli hale gelmiş durumdadır. Dizideki söylemde daha öncelikli hale gelmenin yanında, deneyim, bilgi birikimi, emek sarf etmek ve sonucunda yeteneğin gelişmesi birbirleriyle ilişkili bir sürecin sonunda ortaya çımmamaktadırlar. Oysa, sosyolojik anlamda; deneyim, bilgi birikimi, zaman harcamak, emek sarf etmek yoluyla ortaya çıkan yetenek toplumsal koşullarda ve bir süreç içerisinden meydana gelmektedir. Süreç içerisinde gerçekleşmesi dahi bir toplumsallık içerir. Ancak dizideki söylem içerisinde yetenek, bireysel boyutta yani toplumsal koşullardan soyutlanarak tanımlanmaktadır. Dolayısıyla dizide, başarı sadece kişisel yeteneğe 
indirgenmiştir. Kişisel yetenek de, içinde oluşacağ bireysel koşulların ürünü olarak dile getirilmektedir. Bu yetenek tanımlaması Sennett'in ifade ettiği yeni kapitalist koşullarda istenilen yetenekle uyumlu görünmektedir.

Genel olarak bakıldığında, dizi gerçekliği ile aktarılan örnekte bireylerin toplumsal statülerinde yükselme anlamında farklılaşması, toplumsal ilişkilerde elde edilen başarı sadece bireysel olarak sahip olunan özelliklerle ilişkilendirilerek ele alınmaktadır. Yani başarının, toplumsal boyutu üzerinde durulmamaktadır. Başarı, toplumsal bağlamından kopartılarak bu dizide ele alınmaktadır. Başarı, kişisel özelliklere ve özellikle de yeteneğe indirgenmektedir. Başarının küresel, toplumsal, kültürel ve bireysel şartların toplamında ortaya çıkan bir sonuç olduğu dizi gerçekliğine yansımamaktadır. Bu anlamda, Aliye dizisi yoluyla aktarılanlar, toplumsal yaşamda karşılaşılan örneklere göre sıra dişı kalmaktadır. Ancak diziler genel anlamda gösterdikleri özellikler itibariyle; süreklilik, inandırıcılık özellikleriyle ve sunmaya çalıştığı dünya açısından gerçeklik iddiasındadırlar. Yeniden üretilen dizi gerçekliği ile bireysel başarıların altı çizilmektedir. Toplumsal gerçekliklerden kopuk bir başarı tasavvuru sunulmaktadır. Dolayısıyla başarının bireysel özellikler, koşullar ve imkanlarla oluştuğu anlamı bu dizide tekrarlanarak yeniden üretilmektedir. Başarı-başarısızlığın; dizi gerçekliğinin etkisiyle toplumsal etmenlerin dışında sadece bireye has özellikler, yetenek ve şans ile açıklanmasına bağlı bir başarı-başarısızlık algısının yeniden üretilmesi söz konusudur. "Çağdaş kitle iletişim araçları bugün hem zenginliği hem de fakirliği çok çalışmanın yanında 'şansa' bağlayarak benzer kaderciliği teşvik etmektedir.” (Erdoğan ve Alemdar, 2002, s. 333). Dizide aktarılan başarı özelde kişinin kendi sahip olduğu yetenek gibi kişisel özelliklere bağlanır ve dizi gerçekliğinde başarı çok sık olarak karşımıza çıkar ancak toplumsal pratikte ise, birey başarı sağlayamadığında bu kez başarısızlık içselleştirilerek, bireyselleştirilir. Kişisel başarılar, başarısızlıklar, sorumluluklar, meslek yaşamları yerinden çıkarıcı koşullarda bireyselleştiği için güvensizlik, kaygı gibi duygular yeni kapitalist koşulların insan psikolojisi üzerindeki etkileri olarak açı̆̆a çıkar.

Küresel değişim ve dönüşümlerin, belirsizliklerin, kapitalizmin beraberinde getirdiği şartların bütünü dizideki anlatıma yansımamaktadır. Bunun yanında başarı için gerekli bağlamlar olarak deneyimin, bilgi birikiminin, emek ve zaman sarf etmenin, başarı ya da başarısızlık ile anlamsal ilişkisi yok sayılmaktadır. Başarının ya da başarısızlığın toplumsal bağlamları kaybolmakta, bu televizyon dizisi örneğinde başarının bireysel anlamları güçlenmektedir. "Kişinin hayatını dolduran iyi ve kötü [başarı- başarısızlık] ${ }^{6}$ için sadece o kişi sorumlu tutulur ya da suçlanır. Ve «bütün hayat öyküsü» nün anlatılma tarzı bu varsayımı bir aksiyom mertebesine yükseltir.” (Bauman, 2005, s.19).

Giddens'in (2014, s.33) yerinden-çıkarma olarak nitelediği modern koşullarda toplumsal ilişkilerin bağlamlarından koparılması ve mekânsal zamansal yeni meselelerle ilişkilendirilmesi dizi gerçekliğinde de karşımıza çıkmaktadır. Giddens’ın yaklaşımından hareketle denilebilir ki, öncelikle yetenek kavramı bağlamından kopartılmakta, daha sonra başarı kavramı

\footnotetext{
${ }^{6}$ Parantez içi makale yazarı tarafından eklenmiştir.
} 
bağlamlarından kopartılmaktadır. Ancak toplumsal olaylar karmaşık bir bütünlük içindedir. Birey kendi yaşamında içinde bulunduğu küresel, geç kapitalist, toplumsal, kültürel, ekonomik şartların belirleyiciliği içerisindedir. Bu koşullarda bağlamından kopartılan başarı algısı ile bireylerin yaşam pratikleri çeliştiğinde ise yine Giddens'ın çözümlemesinden hareketle bağlamından kopartılmış başarısızlığın yeniden üretilen alanı-çerçevesi sadece bireyden ibaret olduğu için başarısızlık birey tarafından içselleştirilir. Dizi gerçekliği ve yaşanan gerçeklik arasındaki farklılığa dair insanların bu farklılığı bireysel alana yeni anlamlar yükleyerek aştığı söylenebilir. Güvensizlik, kaygı, güçsüzlük duygusu bu bağlamda açığa çıkar. "Modernitenin mümkün kıldığı hayat tarzı seçenekleri hem birçok elde-etme fırsatı sunar, hem de güçsüzlük duyguları üretir." (Giddens, 2014, s. 251).

\section{Sonuç}

Diziler, gösterdikleri inandırıcılık, süreklilik gibi özellikleriyle bunun yanında gerçekliği yeniden inşa ederek, yerinden çıkararak yarattıkları dizi gerçekliğini toplumsal gerçeklik olarak sunmaktadırlar. Dizi çözümlemesinde ortaya çıan başarı söylemi incelendiğinde, yüzeydeki anlam başarının kolaylıkla elde edilebileceğidir. Dizideki söylem daha derinlemesine analiz edildiğinde altta yatan anlam ise, başarının yetenek ile mümkün olabileceğidir. Aliye dizisinde başarının tek göstergesi vardır. O gösterge de kişisel yetenektir. Dizideki söylemde, yetenek özel bir durum gibi sunulmaktadır. Dolayısıyla yetenek herkeste olmayan bir özellik haline gelmektedir. Bu açıdan söylemde ortaya çıkan anlam, başarının herkese açık değil, kişisel yetenek sahibi olan kişilere açık bir nitelikte olmasıdır. Ancak bu noktada söylem içerisinde yeteneğin nasıl tanımlandığı da önem taşımaktadır. Söylemde ifadesini bulan şekliyle, yeteneğin kaynağının eğitim, bilgi birikimi, deneyim, süreç ile olan ilişkiselliği kurulmamıştır. Yani dizinin başarı söylemi, bir süreç içerisinde meydana gelen bu açıdan da toplumsal özellikler gösteren bir yapıda değildir. Toplumsal özelliklerden, zamansallıktan, birikimsellikten soyutlanmış bir yetenek tasviri söz konusudur. Buna ek olarak dizideki söylemde kişisel yetenek; deneyim ve bilgi birikiminden daha geçerli ve daha öncelikli bir değerde sunulmaktadır. Dolayısıyla dizide saptanan bu özelliklerin yeni kapitalist koşullarla ilişkili olduğu da anlaşılmaktadır. Geç kapitalist koşullarda yetenek; deneyim, bilgi birikimi ve bir işe zaman harcamak karşısında daha az önem taşır hale gelmiştir. Geç kapitalist ve modern koşullar düşünümsel bir biçimde, bir iş alanında başarılı olmayı, yükselmeyi, statü sahibi olmayı sadece kişisel yeteneğe indirgemiştir. Dolayısıyla yeteneği ve başarı-başarısızlığı bağlamından kopartarak yeniden üretmiştir. Yetenek kavramını da toplumsal ilişkilerden ve koşullardan kopuk ve bağımsız olarak tanımlamıştır. Bununla birlikte başarı, geç kapitalist ve modern koşullarda kolay elde edilen bir özellikte tanımlanmıştır. Başarı, sadece kişisel koşullarla, özelliklerle ve yetenekle somutlaşan bir biçimde ortaya çıkmaktadır. Başarı söylemi, kolay elde edilen ve sadece kişisel özelliklerle yani kişisel yetenekle elde edilen bir yapıya sahiptir. Başarı ve başarısızlığın yeniden üretilen kapsamı, alanı bireysel alandan ibarettir. Dolayısıyla, bireyin karşılaştığı toplumsal sorunların aşılması noktasında; başarısızlıkların nedeninin bireysel nedenlerle sinırlamasına ve çözümün, sadece bireysel boyutta çözümlerle aranmasına neden olacaktır. Yetenek, başarı kavramları geç kapitalist ve modern etkilerle bağlamında kopartılmakta sadece bireyin alanına ait bir mesele olarak nitelenmektedir. Başarı ya da başarısızlık; küresel, geç kapitalist şartlar, buna ek olarak bireysel özellikler ve şartlar 
bağlamında ortaya çıkabilen ya da ortaya çıkmayan sosyal bir sonuçtur. Geç kapitalist ve geç modern kültürün etkisiyle televizyon dizisinde başarının, yeteneğin bireysel anlamları güçlenmekte, başarı-başarısızlık bireyselleştirilerek, içselleştirilmektedir.

\section{Kaynakça}

Adorno, T. W., Horkheimer, M. (2014). Aydınlanmanın Diyalektiği. Nihat Ülner ve Elif Öztarhan Karadoğan (Çev.). İstanbul: Kabalcı.

Baudrillard, J. (2016). Tüketim Toplumu: Söylenceleri Yapıları. Hazal Deliceçaylı \& Ferda Keskin (Çev.). 8. Basım. İstanbul: Ayrıntı.

Baudrillard, J. (2018). Simülakrlar ve Simülasyon. Oğuz Adanır (Çev.). 12 basım. Ankara: Doğu Bat1.

Bauman, Z. (2005). Bireyselleşmiş Toplum. Yavuz Alogan (Çev.). İstanbul: Ayrıntı.

Bauman, Z. (2013). Postmodernizm ve Hoşnutsuzlukları. İ. Türkmen (Çev.). 2. Basım. İstanbul: Ayrintı.

Bauman, Z. (2014). Modernite, Kapitalizm, Sosyalizm: Küresel Çağda Sosyal Eşitsizlik. Doruk Ergun (Çev.). 2. Basım. İstanbul: Say.

Cheviron-Tutal, N. (2013). Televizyon ve İçimizdeki Şiddet. İstanbul: Kırmızı.

Doyuran, L. (2018). Medyatik Bir Çalışma Alanı Olarak Eleştirel Söylem Çözümlemesi (Televizyon Dizileri Örneğinde). Erciyes İletişim Dergisi, 5(4), 301-323.

Erdoğan, İ., Alemdar, K. (2002). Öteki Kuram: Kitle İletişimine Yaklaşımların Tarihsel ve Eleştirel Bir Değerlendirmesi. Ankara: Erk.

Erol, E. G. (2009). Asmalı Konak Dizisi ve Filmi Üzerine Anlatı Kuramı Açısından Bir Değerlendirme. Erciyes İletişim, Ocak, 100-114.

Fairclough, N. (2015). Söylemin Diyalektiği. Söylem ve İdeoloji. 2. Baskı. İstanbul: Su.

Fiske, J. (2014). Postmodernizm ve Televizyon, Medya Kültür Siyaset. Süleyman İrvan (Der.). 3. Basım. Ankara: Pharmakon.

Giddens, A. (2014). Modernite ve Bireysel-Kimlik: Geç Modern Çağda Benlik ve Toplum. Ümit Tatlıcan (Çev.). 2. Basım. İstanbul: Say.

Güven-Akdoğan, Ö. (2019). Kadınların Finansal Okuryazarlığı ve Finansal Becerileri Üzerine Bir Yerli Dizi Analizi. Selçuk İletişim, 12(1), 255-275.

Harvey, D. (2010). Postmodernliğin Durumu: Kültürel Değişimin Kökenleri. S. Savran (Çev.). 5. Basım. İstanbul: Metis.

Hobsbawm, E. (2008). Devrim Çă̆ı: Avrupa 1789-1848. B. Sina Şenel (Çev.). 5. Baskı. Ankara: Dost.

İlhan, V. (2014). Medya Çalışmalarında İzleyici: Popüler Bir Tür Olarak Televizyon Dizileri ve İzlerkitle Olarak Gençler. Ankara: Gece. 
Jameson, F. (1994). Postmodernizm yada Geç Kapitalizmin Kültürel Mantı̆̆ı. N. Plümer (Çev.). İstanbul: Yapı Kredi.

Kökpınar-Kaya, E. (2017). Dilsel Kod ve Gösterge Arayüzünde 'Zengin' ve 'Fakir' İnşası: Bir Yerli Televizyon Dizisinin Eleştirel Söylem Çözümlemesi. Sosyoloji Konferansları Istanbul Journal of Sociological Studies, 56, 43-66. https://doi.org/10.18368/iusoskon.328521

Mandel, E. (2013). Geç Kapitalizm. Candan Badem (Çev.). 2. Baskı. İstanbul: Versus.

Mutlu, E. (1999). Televizyon ve Toplum. Ankara: TRT.

Otan, O. (2014). Televizyonda Gerçeklik Algısı. İstanbul: Agora.

Özdemir, H. (2018). Türkiye'de Yerli Televizyon Dizilerinde Toplumsal Cinsiyet Rolleri Açısından Kadının Sunumu: Aşk-I Roman Örneği. Sınırsız Eğitim Araştırma Dergisi, 3(1), 90-107.

Özsoy, A. (2011). Televizyon ve İzleyici: Türkiye’de Dönüssen Televizyon Kültürü ve İzleyici. Ankara: Ütopya.

Postman, N. (2014). Televizyon: Öldüren Eğlence Gösteri Çă̆ında Kamusal Söylem. Osman Akınhay (Çev.). 5. Basım, İstanbul: Ayrıntı.

Poyraz, B. (2002). Haber ve Haber Programlarında İdeoloji ve Gerçeklik. Ankara: Ütopya.

Ritzer, G. (2016). Büyüsü Bozulmuş Dünyayı Büyülemek. Funda Payzın (Çev.). 4. Basım. İstanbul: Ayrintı.

Sennett, R. (2011). Yeni Kapitalizmin Kültürü. Aylin Onacak (Çev.). 2. Basım. İstanbul: Ayrıntı.

Sennett, R. (2017). Karakter Aşınması: Yeni Kapitalizmde İşin Karakter Üzerindeki Etkileri. B. Yıldırım (Çev.). 12. Basım. İstanbul: Ayrıntı.

Storey, J. (2000). Popüler Kültür Çalışmaları: Kuramlar ve Metodlar, Koray Karaşahin (Çev.). İstanbul: Babil.

Tunç, Y., G. Kucur, G., Bilal, M. (Senaryo yazarı). (2004). Aliye [Televizyon dizisi].

Ünür, E. (2015). Yerli Dizilerdeki Kimlik Kalıpları. Konya: Eğitim. 